\title{
AOR
}

Selected Papers of \#AoIR2020:

The $21^{\text {st }}$ Annual Conference of the

Association of Internet Researchers

Virtual Event / 27-31 October 2020

\section{EXPLORING NETWORKED IDENTITY AND TRANSNATIONAL MOBILIZATION IN UKRAINE'S EUROMAIDAN PROTEST}

\author{
Tetyana Lokot \\ Dublin City University \\ Olga Boichak \\ University of Sydney

\section{Introduction}

Social media are a prominent space for diasporic mobilisation and activism, opening new avenues for studying transnational communities living outside of their countries of origin (Andén-Papadopoulos \& Pantti, 2013; Moss, 2016). Unlike entities with clear geographical boundaries, diasporas are transglocal actors (Aparicio, 2010) - networked publics that strategically use technological affordances to mobilize around issues of local, national, and transnational importance. Social media-based narratives produced by these publics can be coupled with ethnographic approaches to empirically study transnational diasporic identity and mobilization in the networked era.

Mapping the datafied representations of diasporic political discourses and practices on social media and triangulating them with qualitative interview data contributes to the growing exploration of innovative, hybrid research methods that increasingly underpin the interdisciplinary study of social and political transformations.

We offer a critical analysis of the digitally mediated transnational activism among Ukrainians living abroad. The political and social upheaval in Ukraine since 2013 resonated with Ukrainian diasporic communities internationally (Lapshyna, 2019), including in the United States. The digitally augmented nature of Euromaidan protests in 2013-2014 also made protest participation highly accessible to diasporic actors (Krasynska, 2014). But how does political engagement work in diasporic settings, where people who share a national identity are physically remote from the center of protest?

Suggested Citation (APA): Lokot, T., Boichak, O. (2020, October 28-31). Exploring Networked Identity and Transnational Mobilization in Ukraine's Euromaidan Protest. Paper presented at AolR 2020: The 21 ${ }^{\text {th }}$ Annual Conference of the Association of Internet Researchers. Virtual Event AolR. Retrieved from http://spir.aoir.org. 
Situating our inquiry in online diasporic communities, our method foregrounds the possibilities for studying transnational mobilization.

\section{Data and Methods}

This study considers how Ukrainians living in the U.S. engaged with homeland politics during the Euromaidan protests, and their use of social media in transnational protest politics. We used historical data from 2014 from three public U.S.-based Ukrainian groups on Facebook (Table 1) to produce a series of semantic maps - networks of nouns that co-occur in a unit of speech - to map the semantic structure of discourse within these groups. This networked approach, where nodes are represented by nouns and edges are weighted according to the frequency of their co-occurrence in a post or comment, allows to detect and map topics without removing the words from their context, and thus helps preserve the meaning embedded in the online narratives. We then conducted 33 in-depth interviews with Ukrainians living in the U.S. (with respondents selected through snowball sampling in communities in Washington, DC and New York, NY), to understand how they engaged with networked protest discourses and made meaning of their digitally mediated participation.

The study considered two key research questions:

RQ1: What is the structure of Ukrainian Americans' platform-mediated discourses on political participation in the context of the protests in their home country?

RQ2: What are the affordances of networked technologies for transglocal protest and how do they co-construct diasporic political participation?

\section{Findings}

The semantic networks from each of the Facebook groups in the U.S. reveal broad similarities in the structure of diasporic discourse about Euromaidan (see maps in Figures 1-3 in Appendices). The key structural features of the discourse were: 1) the centrality of Ukraine-related topics in each of the group discussions (Figure 1); 2) the prominence of political narratives in each of the groups (terms such as "citizen", "community", "freedom," as well as names of key political figures, feature prominently in the semantic maps, as shown in Figure 2); 3) protest-focused discourse connected to particular mediated protest practices ("maidan" (shorthand for Euromaidan), and "action" co-occur with terms such as "help" and "share"); and finally 4) post-Euromaidan, the emergence of war-focused discourse signifying that diasporic activist attention shifted from protests to supporting Ukraine in the conflict with Russia, which began immediately after the protests in the spring of 2014 (Figure 3).

These semantic mapping findings gain deeper meaning in combination with themes that emerged from interviews with Ukrainian diaspora representatives. The respondents felt strongly that their participation in the Euromaidan events was an expression of their political position, as well as a representation of their identity and belonging to Ukraine. Interviewees defined protest engagement as a combination of offline and online actions, including direct action (street rallies); advocacy efforts in mainstream media, social networks and official channels (e.g., letters to Congress); needs-based fundraising and 
charity work; and indirect engagement in activism efforts through anti-corruption investigations. The centrality of protest discussion and related activity in the semantic maps illustrates the key role of social media in mediating diasporic protest participation by layering digital networks over existing diasporic personal connections. This hybrid tandem of personal connections and social networks afforded respondents crucial opportunities for engaging in Euromaidan politics, as they were primarily relying on their strong ties, but achieved wide reach and visibility to the weak ties in the networks.

Importantly, distance from the events on the ground in Ukraine did not appear to influence the volume and depth of political engagement, but rather predicated the tactical choice of activities respondents engaged in and the tools they used. Strategic decisions about choosing to engage in socially mediated information sharing, building support networks and fundraising over other activity allowed the diasporas to preserve and repurpose their networked protest publics when the protest was followed by an armed conflict. The semantic maps indicate that the diasporic online groups directed their attention from the protest to the ensuing war in Ukraine, while the interviews suggest they were able to build on existing networked connections to support their activity.

\section{Contribution}

This study contributes to the broader field of transnational mediated protest participation by using a hybrid methodological approach to examine diasporic mobilization of Ukrainians living in the U.S. during the Euromaidan protests. Triangulating data on online diasporic community practices with in-depth interviews, we show how diaspora members engaged in the protest despite distance and how their activity and tactical decisions were mediated by social networks. We specifically show how diasporic personal networks and networked technologies enmesh into a set of hybrid networked practices, circumscribing how Ukrainian Americans interpret political engagement and how they strategically use the affordances of social media for protest participation. The findings indicate that digitally mediated protest politics can be an important component of studying transnational mobilization and can play a pivotal role in connecting remote diasporic communities to on-the-ground action.

\section{References}

Andén-Papadopoulos, K., \& Pantti, M. (2013). The media work of Syrian diaspora activists: Brokering between the protest and mainstream media. International Journal of Communication, 7, 22.

Aparicio, A. (2010). Transglocal Barrio Politics. In Pérez, G. M., Guridy, F., \& Burgos, A. (Eds.), Beyond El Barrio: Everyday Life in Latina/o America. NYU Press.

Krasynska, S. (2014). Digital civil society: Euromaidan, the Ukrainian diaspora, and social media. In Marples, D. R., \& Mills, F. V. (Eds.), Ukraine's Euromaidan: Analyses of a civil revolution (Vol. 138), 177-198. Columbia University Press. 
Lapshyna, I. (2019). Do Diasporas Matter? The Growing Role of the Ukrainian Diaspora in the UK and Poland in the Development of the Homeland in Times of War. Central and Eastern European Migration Review, 8(1), 51-73.

Moss, D. M. (2016). Transnational repression, diaspora mobilization, and the case of the Arab Spring. Social Problems, 63(4), 480-498.

\section{Appendices}

\begin{tabular}{|l|l|l|}
\hline $\begin{array}{l}\text { Group name } \\
\text { (anonymized to protect privacy of group participants) }\end{array}$ & \# of members & \# of posts \\
\hline Ukrainians in Chicago & 12,823 & 940 \\
\hline Ukrainians in Boston & 2,229 & 1,357 \\
\hline Ukrainians in Seattle & 2,695 & 824 \\
\hline
\end{tabular}

Table 1. Sample descriptives. 


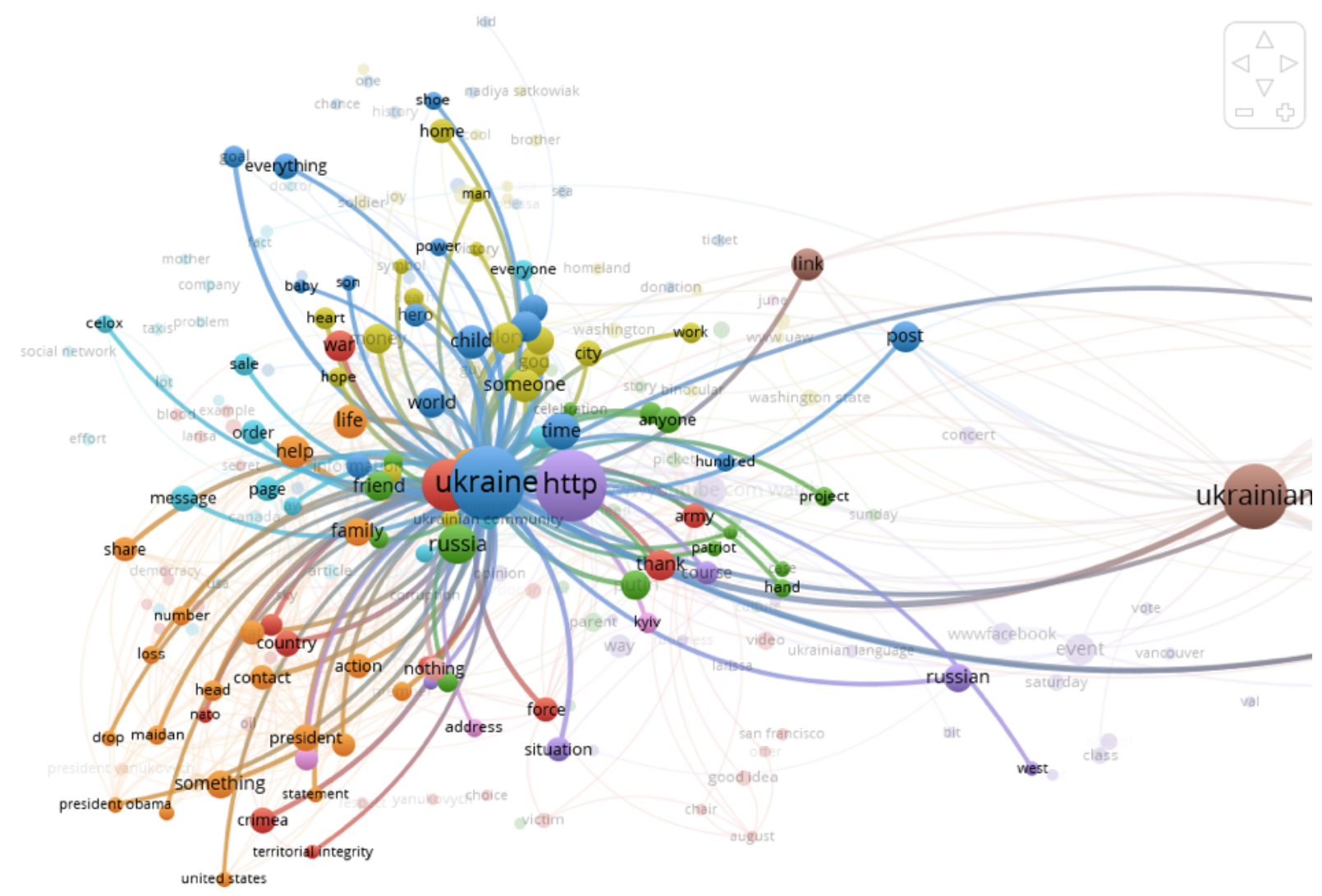

Figure 1. The centrality of Ukraine-related topics in discussion among Ukrainians in Seattle. 


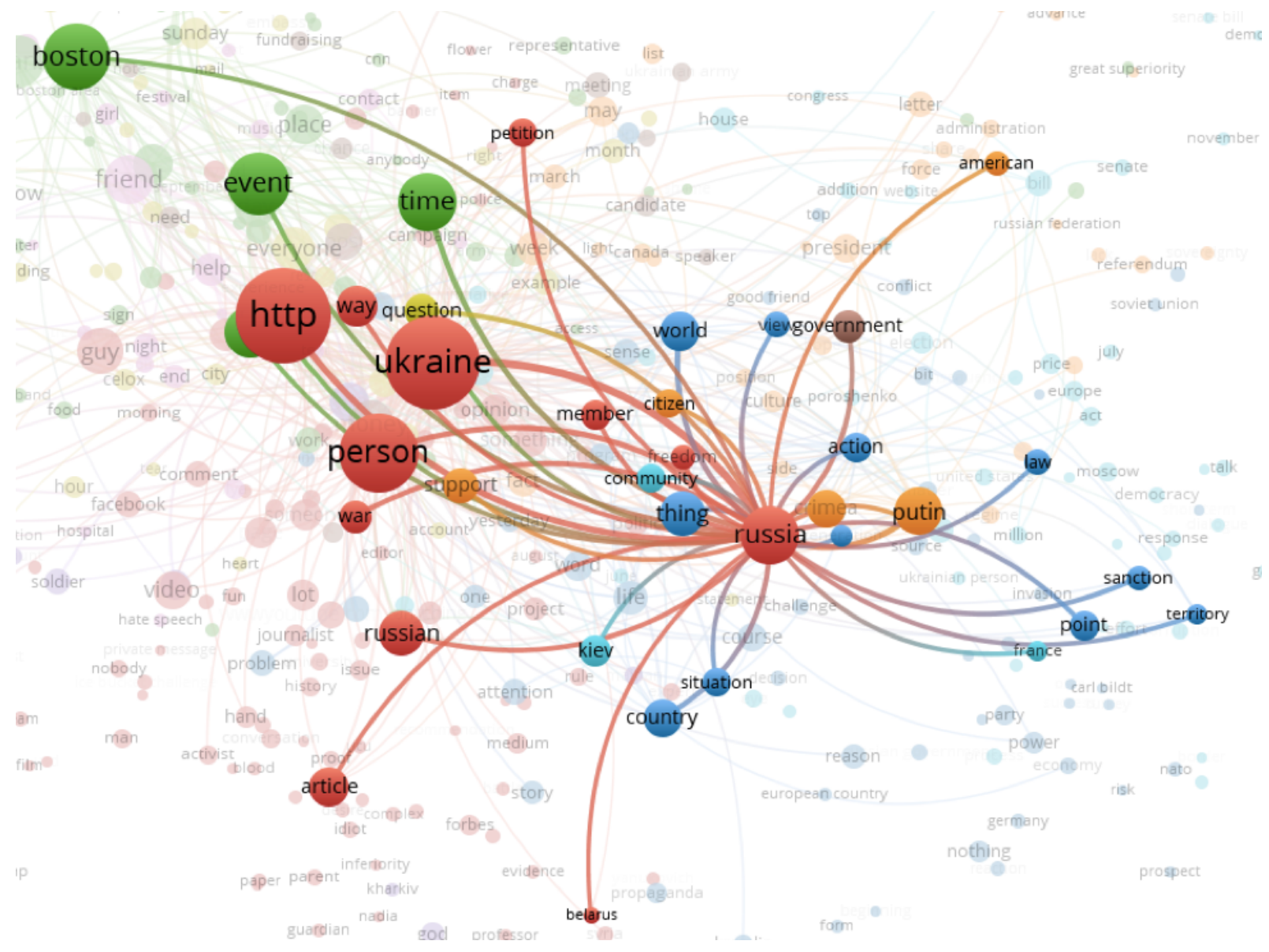

Figure 2. Discussion of Ukraine-related political topics among Ukrainians in Boston.

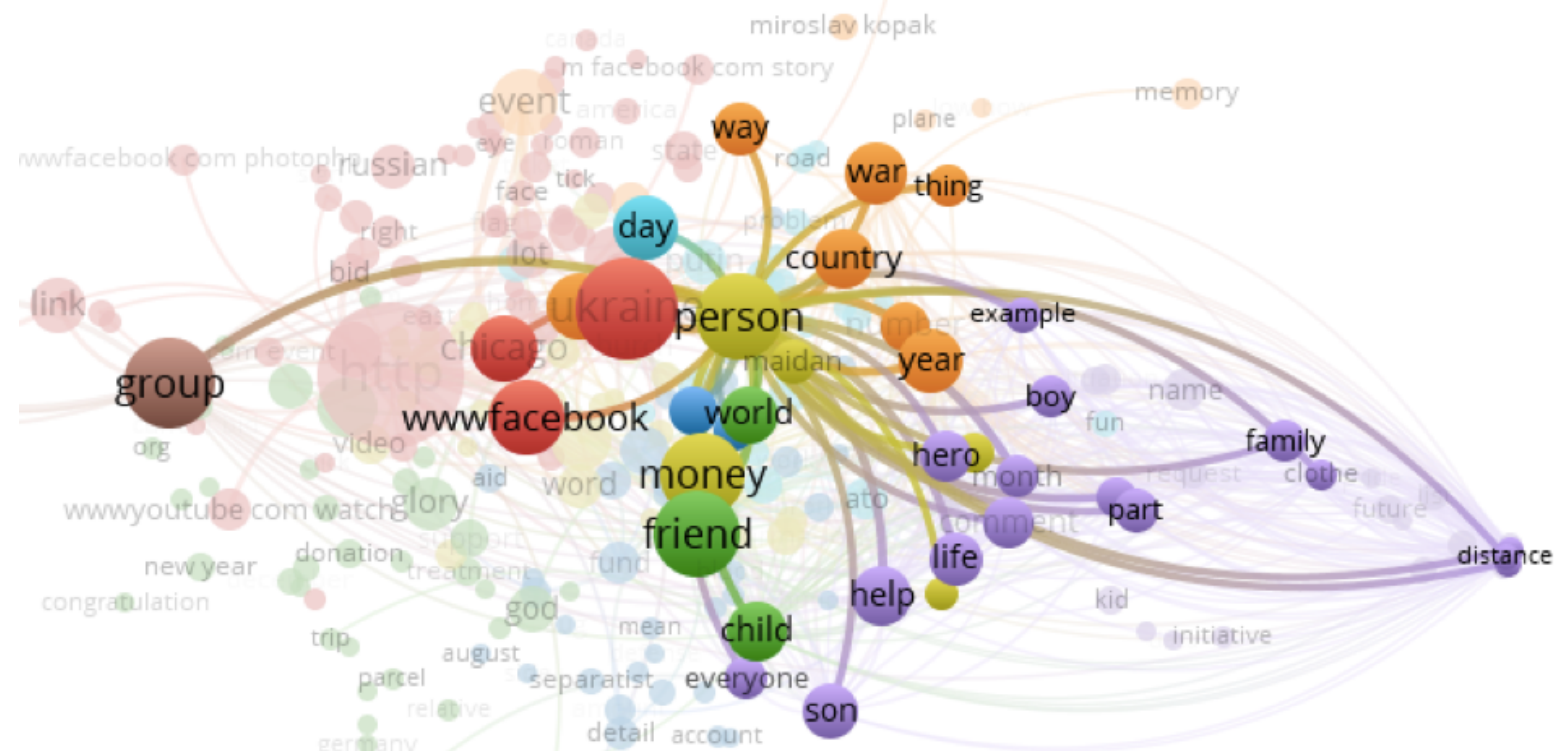

Figure 3. War-related discourses, centering on fundraising, among Ukrainians in Chicago. 